\title{
ISLAMIC STATE INSTITUTE OF BUKITTINGGI STUDENTS' SATISFACTION ON ACADEMIC ATMOSPHERE AND SERVICE
}

\author{
Zulfani Sesmiarni ${ }^{1}$, Darul Ilmi² \\ 1,2IAIN Bukittinggi, Sumatra Barat \\ 1,2Jl. Paninjauan Garegeh Bukittinggi \\ Email: zulfanisesmiarni@gmail.com ${ }^{1}$, darulilmi@gmail.com²
}

\begin{abstract}
:
This research is inspired from the researcher's motivation to see the satisfaction of IAIN Bukittinggi students in terms of academic atmosphere and services. This study was conducted at IAIN Bukittinggi students as population. The sample of research were 438 students. Data collection techniques used in this study were questionnaires to measure satisfaction, academic's atmosphere, and academic services. From the research data, there is a significant influence of Academic Atmosphere on Student's Satisfaction at IAIN Bukittinggi with significant level of $5 \%$. Furthermore, there is a significant influence of the Academic Service on Student's Satisfaction at IAIN Bukittinggi with significant level of 5\%. Then, there is a significant influence of academic atmosphere on academic services at the level of $5 \%$. Finally, there is influence of academic atmosphere and academic service in accordance to student's satisfaction at level of $5 \%$.
\end{abstract}

\begin{abstract}
Abstrak:
Penelitian ini diawali dengan adanya motivasi penulis untuk melihat kepuasan mahasiswa IAIN Bukittinggi ditinjau dari aspek suasana dan pelayanan akademik. Penelitian ini dilakukan di IAIN Bukittinggi dengan populasi mahasiswa, dengan sampel sebanyak 438 orang. Teknik pengumpulan data dalam penelitian ini adalah dengan kuesioner untuk mengukur kepuasan, suasana dan pelayanan akademik. Dari data penelitian maka terdapat pengaruh yang signifikan suasana akademik terhadap kepuasan mahasiswa di IAIN Bukittinggi pada taraf signifikan $5 \%$. Selanjutnya terdapat pengaruh yang signifikan layanan akademik terhadap Kepuasan mahasiswa di IAIN Bukittinggi pada taraf signifikan 5\%. Kemudian terdapat pengaruh yang signifikan suasana akademik pengaruh terhadap layanan akademik pada taraf $5 \%$. Terakhir terdapat pengaruh suasana akademik dan layanan akademik secara bersama-sama hubungan terhadap kepuasan mahasiswa pada taraf $5 \%$.
\end{abstract}

\section{Keywords:}

Students Satisfaction, Academic Atmosphere, Service

INSTITUT Agama Islam Negeri (IAIN) Bukittinggi is a Higher Education Institution under the Ministry of Religious Affairs of the Republic of Indonesia located in Bukittinggi. IAIN Bukittinggi was established in 2014 which is formerly name called Sekolah Tinggi Agama Islam Negeri (STAIN) Bukittinggi. Based on Presidential Regulation No. 181 of 2014, it turned into Institut Agama Islam Negeri (IAIN) Bukittinggi in 2014.

IAIN has been trying to improve the quality and quantity of its students since 2014. In the following years, there is a significant increase in student's number which 
is begun in 2014. This is because IAIN Bukittinggi has been able to open new study program from year to year so that the number of students is increasing. Along with the increasing of student's quantity, this institution also tries to improve the quality of its graduates with various systemic strategies.

It is known that the educational component in an educational institution, in the form of the system, will consist of its supporting elements. The elements are input, process, output, and outcome. Sub-elements of input include students, curriculum, course materials and so forth. For sub-processes, there are learning strategy, classroom management, academic atmosphere, academic service, and environment. Finally, sub-output stands with a qualified graduate. Graduates will achieve maximum results if the input and the process are passed through in the best result as well (Semiawan, 1998: 87).

Academic atmosphere is a condition that must be created to make learning process in Higher Education run in accordance with the vision, mission, and goals. Academic atmosphere is also able to create a conducive climate for academic activities, interaction between lecturers with students, interaction between students, and interaction among lecturers to optimize the learning process.

The academic atmosphere is strongly supported to be developed by doing various ways such as exchange of views and thoughts, symposia, seminars, panel discussions, study group discussions, lectures, practicums, management review meetings on the implementation of Tridharma Perguruan Tinggi, each with its regulations, in the context of educational activities, research, and community service. (Srinadi \& Nilakusmawati, 2008: 60). Moreover, another important point is called academic service. Academic service is a systematic effort of education to facilitate learners to master the contents of the curriculum through learning process so that they are able to achieve the standard competencies applied. Service cannot be removed with rights.

Learning process is considered successful if students have understood themselves and their environment. It is meant that students in the learning process provided by educational institutions through the competence of lecturers and its supporting components must try to later be able to achieve self-actualization properly.

Furthermore, satisfaction is different among individuals. Broadly, an individual has a different level of satisfaction in accordance with the applicable value system. The higher the assessment of the perceived activity in accordance with the wishes of the individual, the higher satisfaction of the activity. Thus, it can be said that satisfaction is an evaluation that describes a person's feelings of pleasure or displeasure in doing activities. Student's satisfaction is the level of feeling in which a person expresses the comparative results of the performance of the product or service received and expected (Departemen Pendidikan Nasional Republik Indonesia, 2008). Someone with a high level of satisfaction indicates a positive attitude. Conversely someone who is not satisfied with his work indicates a negative attitude. 
Based on the above description, as the direction of this research, the scope of this study is limited and not holistic. Specifically, it is only about the influence of academic atmosphere and academic service on student satisfaction at IAIN Bukittinggi in 2016.

Among all of the phenomena illustrated, the following problems are identified: a) Good academic atmosphere will bring satisfaction to students, b) Excellent academic service will make students feel satisfied, c) High satisfaction is one of the determinants of student success in his study's progress d) Educative interaction will bring students a sense of security and comfort in the campus, and e) Positive attitude of students will create a pleasant academic atmosphere.

Based on the identification of the problem, this research is limited in determining: a) academic atmosphere at IAIN Bukittinggi, b) academic service at IAIN Bukittinggi, and c) student's satisfaction at IAIN Bukittinggi.

Based on the research problems that have been previously discussed, the research questions: (1) Does the Academic Atmosphere have an influence on Student Satisfaction at IAIN Bukittinggi? (2) Does the Academic Service have an influence on student satisfaction at IAIN Bukittinggi? (3) Does the academic atmosphere have an influence on academic services? (4) Are the academic atmosphere and academic service jointly related to student satisfaction?

Based on the research questions above, the purpose of this study: (1) To know whether the Academic Atmosphere has an influence on Student Satisfaction at IAIN Bukittinggi, (2) To know if Academic Service has an effect on Student Satisfaction at IAIN Bukittinggi, (3) To find out whether the academic atmosphere has an influence on academic services, (4) To find out whether the academic atmosphere and academic service have a relationship to student satisfaction.

\section{RESEARCH METHOD}

This is a quantitative research using correlational design. The research aims at knowing the relation of a variable with other variables. The relationship between one with several other variables is expressed by the magnitude of the correlation coefficient and significance statistically (Sukmadinata, 2009: 56).

This research is conducted at IAIN Bukittinggi which is located at Jalan Paninjau Garegeh Bukittinggi and Gurun Aua, Kabupaten Agam. The research is conducted in June to October 2016.

The population of this research is all students of IAIN Bukittinggi academic year 2016. Population conditions are explained through the following table: 
Table 1. Population Research

\begin{tabular}{ccc}
\hline No & Faculty & Number \\
\hline 1 & Syariah & 564 \\
2 & Tarbiyah dan Ilmu Keguruan & 3694 \\
3 & Ekonomi dan Bisnis Islam & 1924 \\
4 & Usuluddin Adab dan Dakwah & 169 \\
5 & Post Graduate & 174 \\
\hline & Total & 6525 \\
\hline
\end{tabular}

The sample technique used is Slovin technique by taking $0.05 \%$ sample from population. By using this formula, it is obtained a sample of research with the number 438 students. Next, the technique is stratified and continued with cluster random sampling and finally taken randomly.

The research instrument used is a questionnaire. This instrument is aimed at revealing the academic atmosphere, academic service and student satisfaction. After the data obtained then further performed data analysis requirements to see the data is normally distributed or not. The sample in this study are explained through the following table:

Table 2. Sample Research

\begin{tabular}{clc}
\hline No & \multicolumn{1}{c}{ Faculty } & Number \\
\hline 1 & Syariah & 100 \\
2 & Tarbiyah dan Ilmu Keguruan & 184 \\
3 & Ekonomi dan Bisnis Islam & 104 \\
4 & Usuluddin Adab dan Dakwah & 25 \\
5 & Post Graduate & 25 \\
\hline \multicolumn{2}{c}{ Total } & 438 \\
\hline
\end{tabular}

The research instrument used is questionnaire. Analysis of data that will be implemented in this study is divided into 2 major sections, namely: 1) by using a descriptive statistical approach and 2) by using regression. Both of these techniques were used together in data analysis and become a single entity of the overall data analysis in this study. Besides, there were also the use of path analysis (analisis jalur).

Method consists of description of research type, data collection, data source, data type, and data analysis. It is written in a paragraph form. 


\section{RESULTS AND DISCUSSION}

\section{Findings}

Based on the results of research that has been done to IAIN Bukittinggi students by measuring the atmosphere Academic, Academic Services and Student Satisfaction, it can be explained several things. To describe the academic atmosphere of IAIN Bukittinggi students, it can be seen from the following description:

Based on the data on the research findings, it can be seen the percentage of academic atmosphere in the category of less good $8 \%$ in all faculties except the FEBI faculty with $1 \%$ only. For the category quite good, FUAD and Post graduate faculties are equally the same. The lowest category belongs to FEBI, FTIK and FSYAR faculties. Finally, for the good category, it belongs to FEBI faculty with the highest percentage followed by FTIK, FSYAR, FUAD and PPs faculties.

The good academic atmosphere lies in the Faculty of Ekonomi Islam followed by the Tarbiyah's Faculty, Postgraduate, Syari' ah Faculty, and FUAD Faculty. In general, the state of academic atmosphere at IAIN Bukittinggi is quite good.

To see the percentage of academic services for each faculty, it can be explained as follows:

Based on the data on the research findings, it can be seen that the large percentage of academic atmosphere in the category of not good on the FSyar and FTIK faculties. The bad category is in FSyar faculty followed by FTIK, FUAD, PPs and FEBI faculties. Good enough Category with the highest percentage belongs to PPs, FUAD, FSYAR, FEBI and FTIK faculties. Meanwhile, the good category belongs to FTIK, FEBI, FSYAR, FUAD and PPs faculties. For the most excellent category belongs FEBI, FUAD and FTIK faculties.

Academic Service with the highest average is shown at Ekonomi Islam Faculty. It is followed by Tarbiyah's, Postgraduate's, UAD's, and FSYAR's faculties. In general, the condition of academic services at IAIN Bukittinggi is quite good.

To see the percentage of student satisfaction of each faculty, according to the data, it can be explained that the criteria are not satisfactorily owned by FTIK's and FSYAR's faculties with the highest percentage. Unsatisfactory criteria for the highest sequential percentages belong to FSYAR's, FTIK's, PPS's, FEBI's, FUAD's faculties. The criterion of satisfactory belongs to FUAD's, PPs's, FSYAR's, FTIK's and FEBI's faculties for the highest percentage in sequence. For categories satisfying with the highest percentage to the lowest belong to FEBI's, FTIK's, FSYAR's, FUAD's and PPS's faculties. For the very satisfactory category belongs to FUAD's and FEBI's faculties.

Academic Satisfaction State from the highest average belongs to Ekonomi and Bisnis Islam (FUAD), FUAD's, PPs's, FTIK's and Fsyar's faculties. In general, IAIN Bukittinggi students' satisfaction is in the quite satisfactory category.

Meanwhile, to answer the research hypothesis, it can be described as follows: 
There Is A Significant Influence of Academic Atmosphere on Student Satisfaction at IAIN Bukittinggi at Significant Level Of 5\%.

From the statistic calculation, it is obtained rxy1 equal to 0,480 with significant level $5 \%$ with $r$ arithmetic is 0,098 . Then, it turns that $r$ count is greater than $r$ table. Thus, it rejects the null hypothesis and alternative hypothesis accepted. It means there is a significant relationship between variables $x 1$ to variable $y$.

The relationship of academic atmosphere to student satisfaction is 0,480 . The magnitude of $R$ is 0.480 . This finding can be used to see the magnitude of the influence of the academic atmosphere on student's satisfaction with the coefficient of determination of $48 \%$. This number means that the effect of other factors is $52 \%$. This can be an academic atmosphere affect toward student's satisfaction which can also be caused by many other factors that may give more influence toward student's satisfaction itself.

\section{There Is A significant Influence of Academic Service on Student Satisfaction at IAIN Bukittinggi at Significant Level 5\%}

From the calculation of statistic, it is obtained that $\mathrm{r}$ arithmetic of 0.625 at a significant level of $5 \%$ with $r$ table is 0,098 . Thus, it turns that $r$ count is greater than $r$ table. Then, null hypothesis is rejected. It means there is a significant relationship between the academic service to student's satisfaction.

The correlation of academic service to student's satisfaction is 0.625 that shows high correlation. To see the magnitude of its influence, it can be seen through determination. The figure of $62.5 \%$ means that academic services have a great influence on student's satisfaction

There Is A Significant Influence of Academic Influence on Academic Services with The Level of $5 \%$.

Based on calculation of statistic, it is obtained that $r$ count is 0.596 at the significant level $5 \%$ with $r$ table is 0,098 . Then, it turns that $r$ count is greater than $r$ table. Thus, the null hypothesis is rejected. It means there is a significant relationship between the academic atmosphere of academic service.

The relation of academic service toward student's satisfaction is 0.596 with high correlation. To see the magnitude of its influence, it can be seen through determination with the obtained number of $59.6 \%$. It can be presumed that the academic atmosphere has a great influence on the academic service.

\section{There Is Influence of Academic Atmosphere and Academic Service toward Student's Satisfaction at Level 5\%.}

From statistic calculation, the amount of $\mathrm{r} \times \mathrm{y}$ is 0,639 with the significant level of $5 \%$ which $r$ table is 0,098 . Then, it turns that $r$ count is greater than $r$ table. Thus, the null hypothesis is rejected or not accepted. It means that there is a significant relationship between the academic atmosphere and academic services to student's satisfaction. The influence of academic atmosphere and academic service on student's 
satisfaction is $63.9 \%$. This is due to many other factors that may give more influence on student's satisfaction.

IAIN Bukittinggi encourages the creation of academic life in an intellectual conducive atmosphere to the implementation of academic freedom, freedom of academic platform, and for scientific transformation processes. These implementations seem beneficial to the development of the academic community, the contribution to the welfare of society, and the reputation of IAIN Bukittingi.

The academic processes at IAIN Bukittinggi encourage an academic atmosphere which is the hallmark of inter-academic interaction with academic freedom and academic freedom (kebebasan mimbar), as well as scientific autonomy which are based on reliable scientific arguments.

The academic atmosphere can be seen from the curriculum. A strong curriculum will build a good academic atmosphere as well. The curriculum that suits the demands of needs and is in line with the times will make a strong curriculum. This is because the curriculum is a set of plans to achieve the objectives of the curriculum itself. In addition, the implementation of a curriculum that should aim to increase faith and piety to God Almighty, to understand and live (cognitive), to be able to implement and act effectively (psychomotor), to live together and useful for others in a cultured society, advanced and modern (affective), and to find and build a complete identity.

Implementation of the curriculum is the learning process in lecture hall. Learning process is an interaction between learning resources with students and environment. The more various learning resources that exist in learning, the more able to improve the academic atmosphere (Sukmadinata, 2009: 131).

Academic atmosphere can also be seen from lecturer factor. Lecturer is the main determinant of the achievement to achieve learning goal. Professional lecturers can place themselves into four competencies; personal, social, pedagogic and professional.

Academic service is a systematic effort of education to facilitate learners master the contents of the curriculum through the learning process so that they are able to achieve the competence of the applied standard (Tim LPM IAIN Bukittinggi, 2018). Quality of academic service is a comparison between the academic services perceived by customers or stakeholders with the quality of academic services expected by customers or stakeholders. If the quality of academic services is felt the same or exceed the quality of service expected, the service is said to be qualified.

Satisfaction is something that is individual. Each individual has a different level of satisfaction in accordance with the applicable value system. The higher the assessment of the perceived activity in accordance with the wishes of the individual, the higher the satisfaction of the activity. Broadly, it can be said that satisfaction is an evaluation that describes a person's feelings of pleasure or displeasure in the move.

In brief, customer satisfaction is the level of feeling in which a person expresses the result of comparison of the performance of the product or service received and expected. Someone with a high level of satisfaction indicates a positive attitude. 


\section{Discussion}

Components of educational resources designed and managed in accordance with the specified quality standards will be able to create a conducive academic atmosphere, resulting in excitement in the learning process. With reference to this indicator, it is hoped that the role of university management (PT) and its institutional civitas can improve motivation, creativity, seriousness and regularity to ensure the achievement of the quality standard of the learning process (Istarani, 2015).

It is not easy to describe the "atmosphere" that can be said good or conducive. The atmosphere has neither physical form nor dimension with clear benchmarks. Conducive academic atmosphere can be recognized and felt even if it is abstract and intangible.

The faculty is monitored by a list of attendance of students and lecturers in each subject covered by the lecturers concerned, the number of practical work guidance, final assignment, and practical guidance. This attendance list is very important with regard to the implementation of final evaluation and evaluation for quality assurance (Tim LPM IAIN Bukittinggi, 2018: 107).

The indicators of academic atmosphere are 1. Convenience of the atmosphere of administration and teaching space, 2. Availability of public facilities and infrastructure, 3. Togetherness and collaboration in learning.

Zeithaml dan Berry (1990: 40) simplifies ten into five dimensions which are stated by SERVQUAL dimensions, namely: 1 . Tangibles (service quality in the form of office physical means, computerized administration, waiting room, place of information, etc.); 2 . Reliability (ability and reliability to provide reliable service); 3 . Responsiveness (the ability to help and provide services quickly and accurately, and the ability to be responsiveness to consumer's desires); 4. Assurance (ability and friendliness, and courtesy of employees in convincing consumer confidence); 5 . Empathy (firm but attentive attitude from employees to consumers).

Based on the previous understanding, the academic service can be interpreted as an effort made by universities to provide convenience to meet the needs of students in matters relating to academic activities. In this case Sudarman Danim argues that, in respecting the importance of the function of education, it is imperative that institutions provide the public services continuously by improving the quality of their performance (Sudarwan, 1995: 56). He added that the form of quality of educational services, among others, is the occurrence of intensive contact between servants with service users. The service is done on time and sticks on appropriate target, the act of serving is done carefully and comprehensively, and facing problems that cannot be touched transparently.

Providing excellent service to customers has a goal to meet customer expectations and needs to achieve a satisfaction. Satisfaction itself consists of two things: service and product service activities. Both must qualify in order to provide satisfaction to the recipient of the service. Service must be in a fair quality. Quality of 
service is the suitability between service expected by customer with service expected by organization.

Academic services are intended as services related to academic regulations, lectures, curriculum, academic guidance/counseling, practicum, final assignment, evaluation. They include lecture tools such as libraries, OHPs, laboratories, and others (Pakpahan, 2004: 49).

Satisfaction is something that is completely individual. Each individual has different level of satisfaction in accordance with the applicable value system. The higher the assessment of the perceived activity with the wishes of the individual, the higher the satisfaction of the activity. Thus, it can be said that satisfaction is an evaluation that describes a person's feelings of pleasure or displeasure in the move.

Moreover, students in integrated university quality management are the customers to give satisfaction. For member satisfaction to student, it is important to know what predominant factor determines the level of satisfaction. Faculty should be sensitive and continuously evaluate the service system in the case of what variables/indicators should be maintained and improved so that student satisfaction on the services provided continues to increase.

\section{CONCLUSION}

Based on the findings and previous discussion, it can be concluded that there is a significant Influence of academic atmosphere on student satisfaction at IAIN Bukittinggi at a significant level of $5 \%$. There is a significant Influence of Academic Service on Student Satisfaction at IAIN Bukittinggi at significant level of 5\%. There is a significant influence on academic influence on academic services at the level of $5 \%$. There is influence of academic atmosphere and academic service together relation to student satisfaction at level of $5 \%$.

\section{BIBLIOGRAPHY}

Departemen Pendidikan Nasional Republik Indonesia. (2008). Kamus Besar Bahasa Indonesia (4th ed.). Jakarta: Balai Pustaka.

Istarani. (2015). Ensiklopedi Pendidikan. Medan: Media Persada.

Pakpahan, S. P. (2004). Persepsi Mahasiswa UPBJJ-UT Medan tentang Pelayanan Akademik dan Non-Akademik yang Diberikan oleh UPBJJ-UT Medan. Jurnal Pendidikan Terbuka Dan Jarak Jauh, 5(1), 47-58. Retrieved from http://simpen.lppm.ut.ac.id/ptjj/PTJJ Vol 5.1 maret 2004/51sondang.pdf

Semiawan, C. R. (1998). Pendidikan Tinggi: Peningkatan Kemampuan Manusia Sepanjang Hayat Seoptimal Mungkin. Jakarta: Departemen Pendidikan Nasional.

Srinadi, I. G. A. M., \& Nilakusmawati, D. P. E. (2008). Faktor-Faktor Penentu Kepuasan Mahasiswa terhadap Pelayanan Fakultas sebagai Lembaga Pendidikan (Studi Kasus FMIPA Universitas Udayana). Cakrawala 
Pendidikan, 17(3), 217-231. Retrieved from https://www.researchgate.net/profile/Desak_Putu_Nilakusmawati/publication/3 01634963_FAKTOR-

FAKTOR_PENENTU_KEPUASAN_MAHASISWA_TERHADAP_PELAYA NAN_FAKEUTAS_SEBAGAI_LEMBAGA_PENDIDIKAN_Studi_Kasus_di _FMIPA_Universitas_Udayana/links/571f0c0e08aed056fa227870/FÄK

Sudarwan, D. (1995). Pendidikan Media Komunikasi. Jakarta: Bumi Aksara.

Sukmadinata, N. S. (2009). Metode Penelitian Pendidikan. Bandung: Remaja Rosdakarya.

Tim LPM IAIN Bukittinggi. (2018). Sistem Penjaminan Mutu Internal. Bukittinggi: IAIN Pres.

Zeithaml, P., \& Berry. (1990). Delivering Quality Service: Balancing Customer Perceptions and Expectations. USA: The Free Press. 